\title{
Analysis of Loneliness Levels and Digital Game Addiction of Middle School Students According to Various Variables
}

\author{
Nurullah Emir Ekinci ${ }^{1, *}$, Ilimdar Yalcin² \& Cihan Ayhan ${ }^{3}$ \\ ${ }^{1}$ School of Physical Education and Sport, Kutahya Dumlupinar University, Kutahya, Turkey \\ ${ }^{2}$ Department of Physical Education and Sport, University of Bingol, Bingol, Turkey \\ ${ }^{3}$ Faculty of Sport Science, Sakarya University of Applied Sciences, Sakarya, Turkey \\ *Correspondence: School of Physical Education and Sport, Kutahya Dumlupinar University, Kutahya, Turkey. \\ E-mail: ekinciemir@gmail.com
}

Received: October 8, 2018

Accepted: December 27, 2018 Online Published: January 17, 2019

doi:10.5430/wje.v9n1p20

URL: https://doi.org/10.5430/wje.v9n1p20

\begin{abstract}
The aim of this study was to examine the loneliness levels of students at the middle school level and their digital game addictions in terms of various variables. The study group consisted of 404 volunteer students in 5th-8th grade in Kutahya, Turkey. As data collection tools, "Digital Game Addiction Scale", developed by Lemmens et al. (2009) and "UCLA Loneliness Scale" developed by Russell et al. (1980) were used. The SPSS package program was used for the analysis of the data. According to research findings, it was found that there was a statistically significant difference between the levels of digital game addiction and loneliness according to participation status to sports activities $(p<0,05)$. Moreover, it was found that the levels of both loneliness and digital game addiction of the participants to sports activity were lower than non-participating. When gender and age variables were examined, it was determined that there was a statistically significant difference between digital game addiction, gender, and age $(\mathrm{p}<0,05)$, whereas there was no statistically difference between loneliness level and both variables $(\mathrm{p}>0,05)$. In addition, it was determined that there were a moderate level and positive relationship between the level of loneliness and digital game addiction of middle school students.
\end{abstract}

Keywords: students, sports, loneliness, digital game addiction

\section{Introduction}

One of the most important social functions of education is the preparation of children in society for the future and the continuity of society. This common task in all societies is assessed as meeting the mental, emotional, social, and psychological needs of children as well as their physical needs such as nutrition, shelter, and health. It is clear that a healthy community is composed of healthy individuals both physically and psychologically (Özdemir, 2015). In this respect, passing students around the world through a successful educational process has become one of the main objectives of education and society (Haghbin, et al. 2013; Badua \& Badua, 2018). In the education process, the games have an important place and role in terms of development and learning (Kayabaşı \& Akbaş, 2017; Badua, et al. 2018). The game, which played an important role in the development of the child, has been observed to support instinctual achievement and progress if it is used effectively and correctly. It has been observed that especially numerical based games strengthen hand-eye coordination, problem-solving and multitasking competence (Saka $\&$ Aktürk, 2012).

In recent years, the technological developments that have been experienced and the convenience of accessing technological devices (computer, tablet, and phone) accordingly constitute a great obstacle for the students to achieve a healthy education in the education process by increasing their addiction on digital games (Gürcan et al. 2008). Excessive and inappropriate use of computers and the internet by the students in school-age can cause negative effects on social relations and adversely affect both academic and personal development (Qin \& Nan, 2010; Harris, 2001). In the literature game addiction has been described as an impulse control disorder characterized by symptoms such as "the inability to control the time spent on game-playing", "a loss of interest in other activities", "continuing to play despite the adverse effects" and "feeling psychologically deprived when not being able to play" (Yalçın Irmak, 
\& Erdoğan, 2016; Yalçın Irmak, \& Erdoğan, 2015). According to Qin \& Nan (2010), there are ten standard rules for diagnosing symptoms of game addiction:

- Having strong request or impulsion for internet usage,

- Dissatisfying the time of internet usage,

- Eliminating displeasure and worry once using internet,

- Feeling discomfort in case of stopping,

- Concealing own frequent online conducts from relatives and friends,

- Regarding online as more important behavior than study,

- Spending much money on internet usage,

- Giving up many other hobbies due to internet usage,

- Remembering internet after stopping internet usage,

- Having alienated and disappointed sensations without using internet (Qin \& Nan, 2010).

Recently, research on excessive gaming has received increasing public attention (Grüsser et al. 2006). With the increase of technological developments, the time that individuals separate into themselves and their environment is decreasing, which causes the individual to be isolated from himself/herself and from the society he lived and becomes lonely (Ekinci, et al., 2015). Many similar studies have been found to our research in the literature. For example, Haghbin et al. (2013), while playing such games, players may forget about everything and get immersed in the game (Haghbin, et al., 2013). According to Yee (2006), as the addiction progress grows, gamers become less interested in hobbies or activities that they used to enjoy and become more fascinated with living inside the game (Yee, 2006). Kuss \& Griffiths (2012) game addiction may lower teenagers' motivation for communicating with other people and consequently impose negative effects on their social relationships (Kuss \& Griffiths, 2012). Therefore, we can say that game addiction causing the students to become lonely.

Loneliness is a multidimensional concept with different meanings under different causes and conditions (Arslan, 2013). Loneliness was defined in different ways by the researchers. While some researchers defined it as a situation related to objective conditions, other researchers defined as completely subjective, and existentially. The common feature of all of them is that the concept of loneliness is a painful emotional state (Eskin, 2001). Several definitions of loneliness are given by some researchers as follows: According to Duyan et al. (2008) a process that exists for humanity and will exist in the future (Duyan et al., 2010), to Davis (1990) it is an experience that is unpleasant but common among children, young people and adults (Davis, 1990). to Demir and Tarhan (2001) it is a common phenomenon especially in adolescence because puberty is an important and developmental process (Demir \& Tarhan, 2001). Rook (1984) defines it as a constant increasing feeling when one is rejected by others, is misunderstood, and has no suitable friends or partners to perform the desired activities (Rook, 1984). It is known that sportive activities have an important place in solving loneliness (Özçelik et al., 2015).

Sports activities provide positive contributions not only to the feeling of loneliness of the individual but also to the physical, social, and emotional development. These activities improved talents such as creativity and leadership functional, and they develop personality characteristics such as aggression, determination, harmony, productive, decisive, respect, and understanding, adherence to rules, cooperation, independence, self-discipline, and diligence (Akgün, 1986).

In this respect, the increasing association of individuals by using sport's integrating and socializing feature suggests that participation of individuals in sports and recreational activities, the maturation of the person, and the completion of the adolescence process in a physically and socially healthy manner are a necessity for the social community (Ekinci, et al., 2015). For this reasons, the aim of present study was to determine whether there is a relationship between gender, participants to sports activities, and age variables of middle school students and their game addiction and loneliness levels.

\section{Method}

\subsection{Research Model}

The research was based on quantitative research design and descriptive cross-sectional study. A general screening model was applied in order to arrive at a general judgment about the universe, in which the whole universe or a 
sample taken from it was scanned (Karasar, 2012). According to Gratton and Jones (2010) this method is perhaps the most commonly used method in social and sport based studies.

\subsection{Research Sample}

A total of 404 [ $(\mathrm{n}=173)$ female, $(\mathrm{n}=231)$ male] primary school students was chosen via the simple coincidence method from several schools and they participated as a volunteer in the study.

\subsection{Data Collection Tool}

UCLA Loneliness Scale: UCLA Loneliness Scale consists of 20 items (11 positives and 9 negatives). The 20 items are rated on a 4-point likert scale in accordance with the rate of frequency, ranging from never (1) to always (4). Scores on the scale range from 20 to 80 with higher scores reflecting greater loneliness (Russell, et al. 1980). The validity and reliability of the scale into the Turkish was carried out by Demir (1989). The internal consistency factor of the Turkish version of the scale was. 96, and test-retest reliability was. 94. In the scale, 1, 5, 6, 9, 10, 12, 15, 16, 19 and 20 numbered items were reverse coded. In the present study "Digital Game Addiction Scale (DGAS-7)" developed by Lemmens et al. (2009) was used in order to determine digital game addiction levels (Yalçın Irmak, \& Erdoğan, 2016). The Turkish adaptation study of the scale was performed by Irmak and Erdogan (2015). The DGAS-7 is a 5-item likert type, single-dimension scale consists of 7 questions. The Cronbach's alpha coefficient was found 0,72 .

\subsection{Analysis of Data}

For the data obtained in the study, the SPSS package program was used and frequency (f) and percent (\%) distributions of the variables were calculated. The Skewness and Kurtosis values were checked for normal distribution of the data. The Skewness and Kurtosis were considered to be valued -2 to +2 (George et al. 2006). Therefore, the independent samples t-test, One-way ANOVA and Pearson Correlation test were used. Tukey test was used to determine the insignificant differences between the groups.

\section{Results}

Table 1. T-Test Results on Loneliness and Digital Game Addiction, According to Gender Variable

\begin{tabular}{lllllll}
\hline Variables & Gender & $\mathrm{n}$ & $\overline{\mathrm{X}}$ & $\mathrm{Sd}$ & $\mathrm{t}$ & $\mathrm{p}$ \\
\hline \multirow{2}{*}{ Loneliness } & Woman & 173 & 45,23 & 7,09 & \multirow{2}{*}{1,157} & \multirow{2}{*}{, 248} \\
\multirow{2}{*}{ Digital Game Addiction } & Man & 231 & 44,37 & 7,56 & & \\
& Woman & 173 & 16,60 & 5,60 & \multirow{2}{*}{$-5,132$} & \multirow{2}{*}{, $000^{*}$} \\
\cline { 2 - 6 }
\end{tabular}

$* \overline{\mathrm{p}<0,01}$

When table 1 was examined, there was no statistically significant difference between loneliness levels of the students according to the gender variable ( $p>0,01)$. A statistically significant difference was found between the level of digital game addiction $(\mathrm{p}<0,01)$ according to the gender variable.

Table 2. One-way ANOVA Test Results on Loneliness and Game Addiction, According to Age Variable

\begin{tabular}{llllllll}
\hline Variables & Age & $\mathrm{n}$ & $\overline{\mathrm{X}}$ & $\mathrm{Sd}$ & $\mathrm{F}$ & $\mathrm{p}$ & Tukey \\
\hline \multirow{5}{*}{ Loneliness } & ${ }^{\mathrm{a}} 11$ & 55 & 45,33 & 6,08 & & & \\
& ${ }^{\mathrm{b}} 12$ & 41 & 44,63 & 7,63 & & & \\
& ${ }^{\mathrm{c}} 13$ & 145 & 44,74 & 7,44 & \multirow{2}{*}{, 235} & \multirow{2}{*}{, 918} & - \\
& ${ }^{\mathrm{d}} 14$ & 100 & 44,88 & 7,31 & & & \\
& ${ }^{\mathrm{e}} 15$ & 63 & 44,05 & 8,29 & & & \\
& Total & 404 & 44,74 & 7,37 & & & \\
Digital Game Addiction & ${ }^{\mathrm{a}} 11$ & 55 & 16,76 & 6,54 & & & \\
& ${ }^{\mathrm{b}} 12$ & 41 & 17,46 & 6,77 & & & \\
& ${ }^{\mathrm{c}} 13$ & 145 & 18,42 & 6,60 & \multirow{2}{*}{13,488} &, $043^{*}$ & a-e \\
& ${ }^{\mathrm{d}} 14$ & 100 & 19,09 & 6,69 & & & \\
& ${ }^{\mathrm{e}} 15$ & 63 & 20,38 & 7,87 & & & \\
& Total & 404 & 18,57 & 6,90 & & & \\
\hline
\end{tabular}

$* \mathrm{p}<0,05$ 
According to table 2, there was no statistically significant difference between loneliness levels of the students according to the age variable $(p>0,05)$. A statistically significant difference was found between the level of digital game addiction according to age variable $(\mathrm{p}<0,05)$. According to these results, a statistically significant difference was found between 11 years old and 15 years old students, whereas there was no statistically significant difference other age groups.

Table 3. T-Test Results on Loneliness and Digital Game Addiction, According to Their Participation in the Sports Activities

\begin{tabular}{lllllll}
\hline Variables & Participate to Sportive Activities & $\mathrm{n}$ & $\overline{\mathrm{X}}$ & $\mathrm{Ss}$ & $\mathrm{t}$ & $\mathrm{p}$ \\
\hline Loneliness & Yes & 198 & 43,04 & 7,55 & \multirow{2}{*}{$-4,658$} & \\
& No & 206 & 46,37 & 6,82 & & \multirow{2}{*}{$000^{*}$} \\
Digital Game Addiction & Yes & 198 & 16,84 & 5,54 & \multirow{2}{*}{$-5,132$} & \\
& No & 206 & 20,23 & 7,64 & & \\
\hline \multicolumn{1}{c}{$* \mathrm{p}<0,01$} & & & & & &
\end{tabular}

When table 3 examined, there was a statistically significant difference between loneliness levels and digital game addiction of the students according to participation in sports activities $(\mathrm{p}<0,01)$.

Table 4. Pearson's Correlation Coefficient between the Loneliness and Digital Game Addiction of Middle School Students

\begin{tabular}{|c|c|c|c|}
\hline \multirow{2}{*}{\multicolumn{2}{|c|}{ Loneliness $r$}} & Loneliness & Digital Game Addiction \\
\hline & & 1 & \\
\hline & $\mathrm{p}$ & & \\
\hline Digital Game Addiction & $\begin{array}{l}\mathrm{r} \\
\mathrm{p}\end{array}$ & $\begin{array}{l}, 658^{* *} \\
, 000\end{array}$ & 1 \\
\hline
\end{tabular}

When table 4 was examined, it was determined that there were moderate level and positive correlation between levels of loneliness and digital game addiction of middle school students.

\section{Discussion}

The present study showed that there were no significant differences between gender and loneliness $(\mathrm{p}>0,01)$. When the related studies are examined, it is seen that study of Cassidy and Asher (1992), support that results (Cassidy \& Asher, 1992). But, according to study of Yilmaz et al. (2008) and Eskin (2001), significant differences were found between gender and loneliness level of the students (Eskin, 2001; Y1lmaz \& Karaca, 2008).

A statistically significant difference between digital game addiction levels was found according to gender $(\mathrm{p}<0,01)$. Previous studies have reported that male students were addicted more than females to play digital games (Bonannoa \& Kommers, 2005; Phillips et al., 1995). Additionally, Bonanno and Kommers (2005) tried to explain this situation as: "the gender difference in time dedicated to playing a game can be attributed to the fact that boys find digital games much more attractive and conducive to their natural cognitive processing" games (Bonannoa \& Kommers, 2005). But according to study of Kim et al. (2008) and Colwell et al. (1995), there were not any significant differences between game addiction and gender (Kim et al., 2008; Colwell et al., 1995).

When we examined loneliness levels according to age, statistically significant difference no found between middle school students $(\mathrm{p}>0,05)$. This result may be due to the fact that the participants' ages were close to each other. When different studies were examined, it was found that, in the study of Oruç (2013), there was no statistically significant difference between age and loneliness (Oruç, 2013), in the study of Özkaya (2017), a statistically significant difference was found between the students aged 21 and 22 and the students aged between 22 and 25 years (Özkaya, 2017).

A statistically significant difference was found between the level of digital game addiction according to age variable $(\mathrm{p}<0,05)$. According to these results, a statistically significant difference was found between 11 years old and 15 years old students, whereas there was no statistically significant difference between other age groups. As the age increases, it was seen that the students' digital game addiction levels increase. This is thought to be due to parents 
being more tolerant of their time spent with technological devices (mobile devices, computers, tablets, etc.), depending on the age of their children. In the related literature, results supporting this study are included (Eni, 2017; Hazar et al., 2017).

There was a statistically significant difference between loneliness levels and digital game addiction of the students according to participation in sports activities $(\mathrm{p}<0,01)$. According to this result we may say that participating to the sports activities has a positive effect on loneliness and game addiction level of the students. Ekinci et al. (2015) suggested that participation in sports activities contributed to the socialization of the individual, and naturally, this factor contributed to the individual's not to feel lonely (Ekinci et al., 2015). Kim (2016), and Khan et al. (2017), suggested that participating to the sports activities lower game addiction and violent tendencies (Kim, 2016; Khan et al., 2017). However, Ekinci et al. (2016) stated that there was no statistically significant difference in terms of digital game addiction among those who regularly participated in sporting events and those who did not (Ekinci et al., 2016). In addition, Correlation test results between loneliness and digital game addiction show that it was determined that there were moderate level and positive correlation between levels of loneliness and digital game addiction of middle school students $(\mathrm{r}=, 658 \mathrm{p}<0,01)$. As a result of this study, as the level of loneliness increases, digital game addiction also increases. In the study conducted by Durualp and Çiçekoğlu (2013), it is concluded that as the loneliness levels of the individuals' increase, the levels of internet addiction also increase (Durualp \& Çiçekoğlu, 2013). This result supports the results of our study and it is expected that feeling alone will increase the students' addiction level to the technological devices.

As a result, it was found that male participants were more addict to digital games than women, and individuals who participate to sports activities had lower levels of digital game addiction and loneliness than those who do not. In addition, it was observed that as participants' ages and loneliness levels increase, digital game addictions increase, similarly. Finally, it is seen that participating to the sportive activities has a positive effect on loneliness and digital game addiction level of the students. That is why it is suggested that students should be directed to the sportive activities by their parents and educational institutions

\subsection{Limitations and Suggestions}

The present study has a number of limitations. The study group consisted of 404 volunteer students in 5th-8th-grade school students. Loneliness and game addiction in children is a relatively new research topic. It can show as an obstacle for a more comprehensive study that there are not enough studies which relate to sports and the researchers exist are mostly studied for adults. Therefore, it is thought that studies in this area should be increased. Also, further studies may focus on larger example groups. Family economic conditions also can be an important factor to control for further studies, and it will be an excellent factor to check.

\section{Acknowledgments}

This study presented in ERPA International Congresses on Education in Istanbul/TURKEY, 28th June-1st July 2018.

\section{Author Contributions}

All these authors contributed equally on study design, data analyses, and manuscript drafting.

\section{Conflicts of Interest}

The authors declare no conflict of interest.

\section{References}

Akgün, N. (1986). Egzersiz Fizyolojisi (Handbook). Ege Üniversitesi Beden Eğitim ve Spor Yüksekokulu Pub., İzmir, Turkey.

Arslan, Ö. (2013). TV dizilerinde yer alan karekterler ile kurulan parasosyal etkileşim: bağlanma biçimleri ve yalnızlık açısından bir inceleme. Master Thesis, Ankara Üniversitesi, Sosyal Bilimler Enstitüsü, Ankara, Turkey.

Badau, D., \& Badau, A. (2018). The motoric, educational, recreational and satisfaction impact of adventure education activities in the urban tourism environment. Sustainability, 10(6), 2106-2119. https://doi.org/10.3390/su10062106

Badau, D., Baydil, B., \& Badau, A. (2018). Differences among three measures of reaction time based on hand laterality in individual sports. Sports, 6(2), 45-51. https://doi.org/10.3390/sports6020045

Bonannoa, P., \& Kommers, P.A.M. (2005). Gender differences and styles in the use of digital games. Educational 
Psychology, 25(1), 13-41. https://doi.org/10.1080/0144341042000294877

Brown, S.J., Lieberman, D.A., Gemeny, B.A., Fan, Y.C., Wilson, D.M., \& Pasta, D.J. (1997). Educational video game for juvenile diabetes: Results of a controlled trial. Medical Informatics, 22(1), 77-89. https://doi.org/10.3109/14639239709089835

Buchman, D.D., \& Funk, J.B. (1996). Video and computer games in the '90s: Children's time commitment and game preference. Children Today, 24, 2-16.

Cassidy, J., \& Asher, S.R. (1992). Loneliness and peer relations in young children. Child Development, 63(2), 350-365. https://doi.org/10.2307/1131484

Colwell, J., Grodey, C., \& Rhaiti, S. (1995). Computer games, self-esteem and gratification of needs in adolescents. Journal of Community Applied Social Psychology, 5(3), 195-206. https://doi.org/10.1002/casp.2450050308

Davis, B.D. (1990). Loneliness in children and adolescents. Issues in Comprehensive Pediatric Nursing, 13(1), 59-69. https://doi.org/10.3109/01460869009009745

Demir, A. (1989). UCLA yalnızlık ölçeğinin geçerlik ve güvenirliği. Psikoloji Dergisi, 7(8), 14-18.

Demir, A., \& Tarhan, N. (2001). Loneliness and social dissatisfaction in Turkish adolescents. The Journal of Psychology, 135(1), 113-123. https://doi.org/10.1080/00223980109603684

Durualp, E., \& Çiçekoğlu, P. (2013). Yetiştirme yurdunda kalan ergenlerin yalnızlık düzeylerinin internet bağımlılığı ve çeşitli değişkenler açısından ıncelenmesi. Dokuz Eylül Üniversitesi Sosyal Bilimler Enstitüsü Dergisi, 15(1), $29-46$.

Duyan, V., Duyan, G.Ç. Çifti, E.G., Sevin, Ç., Erbay, E., \& İkizoğlu, M. (2010). Lisede okuyan öğrencilerin yalnızlık durumlarına etkieden değişkenlerin incelenmesi. Eğitim ve Bilim, 33(150), 28-41.

Ekinci, N.E., Demirel, M., Demirel Harmandar, D., \& Işı1k, U. (2015). Lise öğrencilerinin yalnızlık algılarının rekreasyonel etkinliklere katılımları ve bireysel değişkenlere göre incelenmesi. Sportif Bakıļ: Spor ve Eğitim Bilimleri Dergisi, 2(2), 71-78.

Ekinci, N.E., Ustun, U.D., \& Ozer, O. (2016). An investigation of the relationship between digital game addiction, gender and regular sports participation. Journal of Education Culture and Society, 6(2), 298-303.

Eni. B. (2017). Lise ögrencilerinin dijital oyun bağımlılı̆̆ ve alglladıkları ebeveyn tutumlarının değerlendirilmesi. Master Thesis, Haliç Üniversitesi, Sosyal Bilimler Enstitüsü, İstanbul, Turkey.

Eskin, M. (2001). Ergenlikte yalnızlık, baş etme yöntemleri ve yalnızlığın intihar davranışı ile ilişkisi. Klinik Psikiyatri, 4(5), 5-11.

George, D., \& Mallery, M.P. (2006). Using SPSS for Windows Step By Step: A Simple Guide and Reference (7th ed.). Allyn \& Bacon: Boston, USA, ISBN 0205515851.

Grüsser, S.M., Thalemann, R., \& Griffiths, M.D. (2006). Excessive computer game playing: evidence for addiction and aggression? CyberPsychology \& Behavior, 10(2), 290-292. https://doi.org/10.1089/cpb.2006.9956

Gürcan, A., Özhan, S., \& Uslu, R. (2008). Dijital oyunlar ve çocuklar üzerindeki etkileri. Ankara: Başbakanlık Aile ve Sosyal Araştırmalar Genel Müdürlüğü.

Haghbin, M., Shaterian, F., Hosseinzadeh, D., \& Griffiths, M.D. (2013). A brief report on the relationship between self-control, video game addiction and academic achievement in normal and ADHD students. Journal of Behavioral Addictions, 2(4), 239-243. https://doi.org/10.1556/JBA.2.2013.4.7

Harris, J. (2001). The effects of computer games on young children - A review of the research (RDS Occasional Paper No. 72). London: Research, Development and Statistics Directorate, Communications Development Unit, Home Office.

Hartmann, T., \& Klimmt, C. (2006). Gender and computer games: Exploring females dislikes. Journal of Computer, 11(4), 910-931. https://doi.org/10.1111/j.1083-6101.2006.00301.x

Hazar, Z., Demir, G.T., Namlı, S., \& Türkeli, A. (2017). Ortaokul öğrencilerinin dijital oyun bağımlılığı ve fiziksel aktivite düzeyleri arasındaki ilşkinin incelenmesi. Beden Egitimi ve Spor Bilimleri Dergisi, 11(3), 320-332.

Horzum, M.B. (2011). İlköğretim öğrencilerinin bilgisayar oyun bağımlılıklarının çeşitli değişkenlere göre incelenmesi. Eğitim ve Bilim, 36(159), 57-68.

Huge, M.R., \& Gentile, D.A. (2003). Video game addiction among adolescents: Associations with academic 
performance and aggression (Paper presented at Society for Research in Development conference). Tampa, FL, USA.

Karasar, N. (21.Ed.; 2012). Bilimsel Araştırma Yöntemi. Nobel Yayın Publication, Ankara, Turkey, ISBN 9786055426583.

Kayabaşı, Y., \& Akbaş, C. (2017). Eğitsel oyunlar yöntemiyle öğretimin fen bilimleri dersindeki öğrenci başarısına etkisi. Ĕ̌itim ve Öğretim Araştırmaları Dergisi, 6(2), 181-193.

Khan, M.A., Shabbir, F., \& Rajput, T.A. (2017). Effect of gender and physical activity on internet addiction in medical students. Pakistan Journal of Medical Sciences, 33(1), $191-194$. https://doi.org/10.12669/pjms.331.11222

Kim, E.J., Namkoong, K., Ku, T., \& Kim, S.J. (2008). The relationship between online game addiction and aggression, self-control and narcissistic personality traits, science direct. European Psychiatry, 23(3), 212-218. https://doi.org/10.1016/j.eurpsy.2007.10.010

Kim, N.S. (2016). Effects of sport for preventing violence and computer game addiction in youth. International Journal of u-and e-Service, Science and Technology, 9(4), 279-284. https://doi.org/10.14257/ijunesst.2016.9.4.27

Kuss, D.J., \& Griffiths, M.D. (2012). Online gaming addiction in adolescence: A literature review of empirical research. Journal of Behavioral Addictions, 1, 3-22. https://doi.org/10.1556/JBA.1.2012.1.1

Lee, K.M., Park, N., \& Song, H. (2005). Can a robot be perceived as a developing creature? Human Communication Research, 31(4), 538-563. https://doi.org/10.1111/j.1468-2958.2005.tb00882.x

Lemmens, J.S., Valkenburg, P.M., \& Peter, J. (2009). Development and validation of a game addiction scale for adolescents. Media Psychol, 12(1), 77-95. https://doi.org/10.1080/15213260802669458

Lucas, K., \& Sherry, J.L. (2004). Sex differences in video game play: A communication-based explanation. Communication Research, 31(5), 499-523. https://doi.org/10.1177/0093650204267930

Oruç, T. (2013). Üniversite öğrencilerinde psikososyal değişkenlere göre yalnızlık ile otomatik düşünceler ilişkisinin incelenmesi. Master Thesis, Dokuz Eylül Üniversitesi, Eğitim Bilimleri Enstitüsü, İzmir, Turkey.

Özçelik, İ.Y., İmamoğlu, O., Çekin, R., \& Başpınar, S.G. (2015). Üniversite Öğrencilerinin Yalnızlık Düzeyleri Üzerine Sporun Etkisi. Spor ve Performans Araştırmalarl Dergisi, $6(1), \quad 12-18$. https://doi.org/10.17155/spd.18840

Özdemir, N. (2011). Düzenli fiziksel aktivitenin ilköğretim öğrencilerinin okula yabancılaşma ve yalnizlik düzeyleri üzerine etkileri. Doktorate Thesis, Ege Üniversitesi, Sağlık Bilimleri Enstitüsü, İzmir, Turkey.

Özkaya, G. (2017). Üniversite öğrencilerinin yalnızlık düzeyleri ile umutsuzluk ve yaşam doyumu arasındaki ilişki. Master Thesis, Haliç Üniversitesi, Sosyal Bilimler Enstitüsü, İstanbul, Turkey.

Phillips, C.A., Rolls, S., Rouse, A., \& Griffiths, M.D. (1995). Home video game playing in schoolchildren: a study of incidence and patterns of play. Journal of Adolescence, 18(6), 687-691. https://doi.org/10.1006/jado.1995.1049

Qin, X., \& Nan, H. (2010). Study on the causes and strategies of online game addiction among college students. In Proceedings In Multimedia Technology (ICMT), International Conference, 29-31 October 2010; Institute of Electrical and Electronics Engineers (IEEE), Ningbo, China, pp.2254-2257. https://doi.org/10.1109/ICMULT.2010.5630987

Rook, K. (1984). Promoting social bonding: Strategies for helping the lonely and socially isolated. American Psychologist, 39(2), 1389-1407. https://doi.org/10.1037/0003-066X.39.12.1389

Russell, D., Peplau, L.A., \& Cutrona, C.E. (1980). The revised UCLA loneliness scale: Concurrent and discriminant validity evidence. Journal of personality and social psychology, 39(3), 472-480. https://doi.org/10.1037/0022-3514.39.3.472

Saka, H., \& Aktürk, A.O. (2012). The Analysis of Computer Game Addiction of Secondary School Students. In Proceedings 6th International Computer \& Instructional Technologies Symposium, Gaziantep, Turkey, 4th-6th November.

Yalçın Irmak, A., \& Erdoğan, S. (2015). Validity and reliability of the Turkish version of the digital game addiction scale. Anatolian Journal of Psychiatry, 16(Supplement 1), 10-18. https://doi.org/10.5455/apd.170337 
Yalçın Irmak, A., \& Erdoğan, S. (2016). Ergen ve genç erişkinlerde dijital oyun bağımlılığı: güncel bir bakış. Türk Psikiyatri Dergisi, 27(2), 128-137.

Yee, N. (2006). The labor of fun: how video games blur the boundaries of work and play. Games and Culture, 1, 68-71. https://doi.org/10.1177/1555412005281819

Yılmaz, E., \& Karaca, F. (2008). Üniversite öğrencilerinin sosyal destek ve yalnızlık düzeylerinin incelenmesi. Genel Tip Dergisi, 18(2), 71-79. 